\title{
The Relationship Between Nurse Empowerment and Burnout Syndrome In Hospital
}

\author{
Rizeki Dwi Fibriansari \\ Faculty of Nursing Universitas Airlangga \\ Surabaya, Indonesia \\ rizeki.dwi.fibriansari-2015@fkp.unair.ac.id \\ Nursalam Nursalam \\ Faculty of Nursing Universitas Airlangga \\ Surabaya, Indonesia \\ nursalam@fkp.unair.ac.id
}

\author{
Slamet Riyadi Yuwono \\ Poltekkes Kemenkes Surabaya \\ Surabaya, Indonesia
}

\begin{abstract}
Empowerment is necessary for the era of competition and service because every organization needs employees who are fast, responsive and independent so they can be competitive through human resources and strengthen the capability and commitment of employees. The lack of empowerment of nurses in hospitals related to stress due to poor working conditions and one of the main causes of nurses' burnout. The purpose of this study was to determine the relationship between nurse empowerment and burnout syndrome. This study used a cross-sectional approach and 137 nurses collected as respondents by multistage sampling. The first phase used cluster sampling, the second phase used a proportional random sampling, and the last phase used simple random sampling. Data were collected by the questioner and were analyzed by using Pearson correlation with a significance level of 0.01 . The result showed empowerment was significantly related to burnout syndrome. Structural empowerment was negatively related with burnout syndrome $(r=-0.110)$ and psychological empowerment too $(r=-0.091)$. It means that the higher empowerment, the lower level of nurses' burnout. On the other hand with a sense of responsibility given to the nurses can trigger feelings of fatigue affecting job satisfaction of nurses. Strategy empowerment so important to reduce burnout syndrome in the working environment of nursing.

Keywords: empowerment, burnout, nurse, hospital
\end{abstract}

\section{INTRODUCTION}

Human resources are very important factor in a service [1]. Human resources in hospitals consist of various professions including health workers that include medical (doctors), paramedics (nurses) and non-nursing paramedics and nonhealth workers including the administration, personnel, and finance [2]. Nursing resource is an asset and essential component in the hospital services that contribute in defining the image of the hospital [3].

Utilization of human resources as an effort to empower employees at the hospital [4]. Empowerment is important because in the era of competition and service, every organization needs employees who are fast, responsive and independent so that they can be competitive through human resources and strengthening the capability and commitment of the employees[5].

Human resource development, especially nurses in Dr. Haryato Lumajang hospitals continue to provide nurses an opportunity for continuing education, training, seminars and workshops to improve the knowledge, competencies, and skills. Most of the inpatient wards at the Dr. Haryato Hospital Lumajang use team models, and each room team consists of 23 teams. Team models will provide an opportunity for the team leader to be responsible for the nursing care given to the client, so that team members feel empowered to contribute.

Empowerment in nursing will make nurses have a reasonable workload, control over their work and a good working relationship. Also, nurses treated fairly and rewarded for their contribution and recognized the values of the profession by the organization [6].

The perception of nurses in the workplace empowerment structurally will increase the psychological empowerment. Empowered nurses will reduce the level of burnout [7]. Subsequent research Laschinger to develop a theory Kanter, Kanter produce organizational empowerment theory in nurse educator in the Canadian population, a higher level of empowerment is associated with the lower saturation levels and greater job satisfaction [8]. Empowerment behavior in leaders can improve nurse job fit and prevent burnout [6].

Nurse empowerment in the workplace will provide opportunities for better performance, but when in the less condition, the nurse will feel helpless [9]. This threatens the productivity of the organization for nurses who are not empowered more susceptible to burnout and reduced job satisfaction [8].

The hospital is also required to empower nurses as much as possible to create job satisfaction to improve job performance of the nurses. Therefore, nursing manager plays a major role in creating a positive work environment to create an enormous impact on nurses working conditions and improve the quality of services to the patient. 


\section{MethodS}

This study used a cross-sectional approach. The population in this study were nurses in Dr. Haryato Lumajang hospitals. The samples were 137 nurses at the Dr. Haryato Hospital nurse who met criteria: as a local nurse over five years, and a minimum of level education is Diploma.

The study used a multi-stage sampling. The first phase, cluster sampling is used to classify nurses working space where the corresponding units consisting of four units, that are critical care (37 nurses), inpatient (57 nurses), outpatient (20 nurses) and operating room (23 nurses). The second phase used proportional random sampling by considering the number of respondents representing each unit. The third phase used simple random sampling.

Variable in this research are empowerment and burnout syndrome. Empowerment divided into structuran environment and psychological empowerment. Measurements of structural empowerment used Condition for Work Effectiveness Questionnaire (CWEQ) that measure four dimensions of structural empowerment include access to opportunity, support, information, and resources [6]. Formal power was measured by using the Job Activities Scale (JAS) and informal power using the Organizational Relationship Scale (ORS). While the measurement of psychological empowerment used Psychological Empowerment Scale (PES) includes four dimensions of meaning, confidence, autonomy, and impact [10]. The instrument used to burnout syndrome is Maslach Burnout Inventory (MBI).

Data were analyze using the Statistical Package for Social Sciences Version 22 (IBM SPSS v22) and Pearson Correlation was used to analyze the relationship between empowerment and burnout syndrome. Cronbach's alpha reliability test is 0.719 (> 0.6) so that the instrument is considered reliable [11].

\section{RESULTS}

Based on the nurse's demographics in Dr. Haryoto Hospital Lumajang, $70,8 \%$ were women, and $53.3 \%$ have level education diploma.

Table 1. Observed Mean Value and Precentage INSTRUMENT

\begin{tabular}{clcc}
\hline No. & Instrument & Mean & F (\%) \\
\hline 1. & Structural & 65.8 & 69.3 \\
& empowerment & 11.9 & 79.0 \\
a. & Opportunity & 9.9 & 65.7 \\
b. & Information & 10.2 & 67.9 \\
c. & Support & 10.6 & 70.9 \\
d. & Resources & 9.5 & 63.6 \\
e. & Formal power & 13.8 & 68.9 \\
f. & Informal power & 45.7 & 76.2 \\
\hline 2. & Psychological & 11.8 & 78.4 \\
& empowerment & 12.0 & 79.7 \\
a. & Meaning & 11.0 & 73.1 \\
b. & Confidence & & \\
c. & Autonomy &
\end{tabular}

\begin{tabular}{clcc} 
d. & Impact & 11.4 & 73.4 \\
\hline & $\begin{array}{c}\text { Overall } \\
\text { Empowerment }\end{array}$ & 55.75 & 72.75 \\
\hline No. & \multicolumn{1}{c}{ Instrument } & Mean & F (\%) \\
\hline 3. & $\begin{array}{l}\text { Burnout } \\
\text { syndrome }\end{array}$ & 55.4 & 50.4 \\
a. & $\begin{array}{l}\text { Emotional } \\
\text { exhaustion }\end{array}$ & 18.7 & 41.6 \\
b. & $\begin{array}{l}\text { Depersonalization } \\
\text { c. }\end{array}$ & 8.2 & 32.8 \\
& $\begin{array}{l}\text { aecomplishment } \\
\text { acconal }\end{array}$ & 28.5 & 71.2 \\
\hline
\end{tabular}

Based on Table 1, empowerment has two sub-variable, there are structural empowerment and psychological empowerment with the mean was 65.8 and 45.7 respectively. Thereby, the overall of the mean value of the each item in empowerment was 55.75. While The mean of burnout syndrome was 55.4 .

TABLE 2. THE RELATIONSHIP BETWEEN EMPOWERMENT AND BURNOUT

\begin{tabular}{llcc}
\hline & Variable & \multicolumn{2}{c}{ Burnout Syndrome } \\
\cline { 3 - 4 } & $\begin{array}{c}\text { Sig } \\
(2-t a i l l e d)\end{array}$ & Pearson Correlation \\
\hline 1. & $\begin{array}{l}\text { Structural } \\
\text { Empowerment } \\
\text { Psychological } \\
\text { empowerment }\end{array}$ & 0.000 & -0.320 \\
\hline
\end{tabular}

Correlation analyses were conducted to examine the relationship between empowerment dimensions and burnout syndrome further. Empowerment was significantly related to burnout syndrome $(\mathrm{p}=0.000)$. Structural empowerment was negatively related with burnout syndrome $(\mathrm{r}=-0.320)$ and also psychological empowerment $(r=-0.371)$ (see Table 2). So the higher empowerment, the lower level of nurses burnout.

\section{DISCUSSION}

Structural empowerment associated with the involvement of nurses working in accordance with its duties and functions. Formal power, information, and support in the low level may encourage employees to set goals of their work and to give greater authority to make decisions within the scope of employment. This threatens the productivity of the organization for nurses who are not empowered more susceptible to burnout and reduced job satisfaction [12]. Based on the results of interviews, it can be proved by room most of the use of team model. Team models will provide an opportunity for the team leader to be responsible for the nursing care given to the client, so team members feel empowered. On the other hand, a sense of responsibility of the nurses can trigger feelings of unclear job affecting job satisfaction of nurses.

Psychological empowerment can be realized in the role of the nurse. It can affect the spirit or motivation stagnation in employment and careers for nurses. Also nurses 
treated fairly and rewarded for their contribution and recognized the values of the profession by the organization [6]. Based on interviews, the lack of job satisfaction of nurses caused by nurse doing paperwork in service, especially during the evening and night shift, rotation policies from employers regarding job placement so that nurses need readaptation to the new working environment and lack of effective communication with other professional teams.

Burnout of nurses was in moderate level. Burnout is also associated with an imbalance between needs and resources as the fact that burnout is a frustrating set of results that occur in the workplace [13]. The cause of burnout due to a mismatch between the proportion of nurses and workload. It can lead to decreased quality of work, unhealthy relationships in the work environment, lowering creativity nurses and cause burnout.

This study showed that the higher empowerment, the lower level of nurses burnout. Empowerment behavior in leaders can improve nurse job fit and prevent burnout. Structural and psychological empowerment have a significant adverse effect on burnout at the hospital [6].

\section{CONCLUSION AND RECOMMENDATION}

From this study, it can be concluded that workplace and psychologic condition have positive effect for the nurses. Empowering nurses no longer passively waiting for guidance instructions. This condotion can create a better condition for hospital.

Strategy empowerment is so important to increase engagement and reduce burnout syndrome. Nurse managers should create a conducive work environment and improve the quality of services to the patient.

\section{REFERENCES}

[1] M. Hariandja, Manajemen Sumber Daya Manusia. Jakarta: Grasindo, 2002.

[2] S. Salimah, "MODEL 7P PADA MANAJEMEN SDM DI RUMAH SAKIT | Indosdm.com," 2009. [Online]. Available: http://indosdm.com/model-7ppada-manajemen-sdm-di-rumah-sakit. [Accessed: 27Nov-2016].

[3] A. Yatnikasari, "Hubungan program retensi dengan komitmen organisasi perawat pelaksana di RSAB
Harapan Kita," Universitas Indonesia, 2010.

[4] M. Amstrong, Amstrong's Handbook of Human Resource Management Practice. Philadelphia: British Library Cataloguing in Publication Data, 2006.

[5] H. Simamarta and N. Simamarta, "Pemberdayaan Karyawan," 2009. [Online]. Available: http://headtoresearch.blogspot.co.id/2009/04/ pemberdayaan-karyawan.html. [Accessed: 10-Oct2016].

[6] P. Greco, H. Spence Laschinger, and C. Wong, "Leader Empowering Behaviours, Staff Nurse Empowerment and Work Engagement/Burnout," Nurs. Leadersh., vol. 19, no. 4, pp. 41-56, 2006.

[7] H. Laschinger, J. Finegan, J. Shamian, and P. Wilk, "Workplace empowerment as a predictor of nurse burnout in restructured healthcare settings," Healthc. $Q$., vol. 6, no. 4, 2003.

[8] T. P. Sarmiento, H. K. S. Laschinger, and C. Iwasiw, 'Nurse educators' workplace empowerment, burnout, and job satisfaction: testing Kanter's theory," J. Adv. Nurs., vol. 46, no. 2, pp. 134-143, Apr. 2004.

[9] L. Meng, Y. Liu, H. Liu, Y. Hu, J. Yang, and J. Liu, "Relationships among structural empowerment, psychological empowerment, intent to stay and burnout in nursing field in mainland China-based on a cross-sectional questionnaire research," Int. J. Nurs. Pract., vol. 21, no. 3, pp. 303-312, Jun. 2015.

[10] S. Laschinger, M. Leiter, A. Day, and D. Gilin, "Workplace empowerment, incivility, and burnout: impact on staff nurse recruitment and retention outcomes," J. Nurs. Manag., vol. 17, no. 3, pp. 302 311, Apr. 2009.

[11] Nursalam, Metodologi Penelitian Ilmu Keperawatan Pendekatan Praktis, 4th ed. Jakarta: Salemba Medika, 2016.

[12] H. K. Spence Laschinger, "Effect of Empowerment on Professional Practice Environments, Work Satisfaction, and Patient Care Quality," J. Nurs. Care Qual., vol. 23, no. 4, pp. 322-330, Oct. 2008.

[13] V. Torado-Franceschi, Compassion Fatigue and Burnout in Nursing. Enhancing Professional Quality of Life. New York: Springer Publishing Company, 2015. 